\title{
Long Non-Coding RNA LINC00466 Knockdown Inhibits Tongue Squamous Cell Carcinoma Malignancy by Targeting microRNA-493/HMGA2 [Expression of Concern]
}

\author{
Hou C, Dong Y, Du B. Cancer Manag Res. 2020;12:13071 \\ -13084 .
}

The Editor and Publisher of Cancer Management and Research wish to publish an Expression of Concern for the published article. Following publication, concerns were raised about the scientific integrity of the articles content. We reached out to the authors requesting they supply information that would confirm the integrity of the data. The authors provided several files in response to our queries but they did not satisfy our requirements to confirm the authenticity of some types of data. In addition, there were unexplained similarities between some of the figures presented in this article, and figures presented in articles by different authors groups. As yet, the authors have not provided a satisfactory explanation for this.

Therefore, as we continue to work through the issues raised, we advise readers to interpret the information presented in the article with due caution.

The authors have been notified about this Expression of Concern.

\section{Publish your work in this journal}

Cancer Management and Research is an international, peer-reviewed open access journal focusing on cancer research and the optimal use of preventative and integrated treatment interventions to achieve improved outcomes, enhanced survival and quality of life for the cancer patient.
The manuscript management system is completely online and includes a very quick and fair peer-review system, which is all easy to use. Visit http://www.dovepress.com/testimonials.php to read real quotes from published authors. 